\title{
Krucjata antyalkoholowa w Sejmie Ustawodawczym i jej efekty (1919-1922)
}

\section{Streszczenie}

Walka z alkoholizmem była istotnym elementem polityki społecznej II Rzeczypospolitej, a u podstaw działań podejmowanych w tym kierunku legło tworzenie odpowiednich norm prawnych. Największe zasługi w tym względzie należy przyznać Sejmowi Ustawodawczemu, którego dziełem była pierwsza na ziemiach polskich ustawa przeciwalkoholowa. Sprawy krzewienia abstynencji i ograniczenia spożycia wyrobów spirytusowych w żadnej z kolejnych kadencji parlamentarnych nie znalazły już takiego zrozumienia jak w Sejmie Ustawodawczym, którego skład, struktura społeczna oraz podatność na tendencje abstynenckie skutkowały wyraźnie prohibicyjnym nastawieniem w kwestii konsumpcji alkoholu. Uprawniony wydaje się zatem wykorzystany w tytule niniejszego szkicu termin „krucjata antyalkoholowa”. Efektem podejmowanych w Sejmie Ustawodawczym działań stała się ustawa z 23 kwietnia 1920 r. wprowadzająca znaczące ograniczenia w sprzedaży napojów alkoholowych. Co więcej, przepisy ustawy dawały adherentom prohibicji nadzieję na stopniowe jej wprowadzenie w całym kraju. W toku zabiegów o wprowadzenie ograniczeń produkcji, handlu i spożycia alkoholu bardzo wyraźnie zarysował się konflikt między aktywistami walki z alkoholizmem a rządem, zwłaszcza Ministerstwem Skarbu. Ścierały się w nim $\mathrm{z}$ założenia słuszne idee $\mathrm{z}$ interesem budżetu państwa. W starciu tym zdecydowanie zwyciężyli zwolennicy ograniczeń w sprzedaży alkoholu, jednak ich zwycięstwo nie przełożyło się na praktykę, a ustawa z 23 kwietnia 1920 r. nigdy nie została w pełni zaimplementowana. Potwierdzeniem niepowodzenia jej twórców stała się przyjęta przez Sejm 21 marca 1931 r. ustawa o ograniczeniach w sprzedaży, podawaniu i spożyciu napojów alkoholowych (przeciwalkoholowa), która oznaczała oficjalny zwrot ku pragmatyzmowi w tej sferze życia społecznego.

Stowa kluczowe: Druga Rzeczpospolita, polityka społeczna, walka z alkoholizmem, Sejm Ustawodawczy, prohibicja

${ }^{1}$ Dr hab. Paweł Grata, prof. UR, Instytut Historii Uniwersytetu Rzeszowskiego, al. Rejtana 16c, 35-959 Rzeszów, e-mail: pgrata@wp.pl 


\section{Uwagi wstępne}

Walka z alkoholizmem i alkoholem jako używką szkodliwą dla życia jednostki, rodziny i społeczeństwa była jednym z ważnych aspektów polityki społecznej Drugiej Rzeczypospolitej, a u podstaw działań podejmowanych w tym kierunku przez państwo legło tworzenie ograniczających rozmiary spożycia alkoholu norm prawnych. Bezwzględnie największe zasługi w tym zakresie należy przyznać wybranemu u progu niepodległości Sejmowi Ustawodawczemu, którego dziełem stała się nie tylko pierwsza na ziemiach polskich ustawa przeciwalkoholowa, ale również inne inicjatywy zmierzające nawet do wprowadzenia, wzorem kilku innych państw, całkowitego zakazu sprzedaży i konsumpcji alkoholu w kraju. Sprawy krzewienia abstynencji i ograniczenia spożycia wyrobów spirytusowych w żadnej z kolejnych kadencji parlamentarnych nie znalazły już takiego zrozumienia jak właśnie w Sejmie Ustawodawczym, którego skład, struktura społeczna oraz podatność na powszechne w ówczesnych warunkach tendencje abstynenckie skutkowały tak wyraźnie prohibicyjnym nastawieniem w kwestii konsumpcji alkoholu. Stąd też uprawniony wydaje się użyty w tytule niniejszego szkicu termin „krucjata antyalkoholowa”, w dużej mierze trafnie obrazujący podejmowane w Sejmie Ustawodawczym działania w tym względzie.

Kwestia pijaństwa, czy też alkoholizmu, została dostrzeżona jako problem społeczny w modernizujących się społeczeństwach XIX w. Skutki nadmiernego spożywania alkoholu przez szerokie masy ludności, zwłaszcza wiejskiej, były dotkliwie odczuwalne zarówno w zaawansowanych w rozwoju krajach Zachodu, jak i w jeszcze większej mierze w feudalnych wielkich monarchiach Europy Środkowej i Wschodniej. Można nawet uznać, że w efekcie wciąż obowiązujących w Rosji i Austrii przywilejów propinacyjnych, wymuszających niemal spożywanie odpowiedniego kontyngentu alkoholu przez ludność chłopską, pijaństwo stanowiło w tych właśnie częściach kontynentu zjawisko utrwalone zarówno tradycją, jak i prawem. O skali problemu świadczyły zarówno statystyki, jak i pojawiające się liczne relacje obrazujące zasięg zjawiska, a „wsparciem” dla rozwoju konsumpcji alkoholu stał się dokonujący się w tym czasie rozwój opartego na przerobie ziemniaków gorzelnictwa rolniczego (zob. np. Besala 2017; Burszta 1951; Rożenowa 1961).

W reakcji na narastanie problemu zaczęly się pojawiać na ziemiach polskich coraz liczniejsze, w większości związane z Kościołem katolickim, organizacje stawiające sobie za cel walkę ze zjawiskiem pijaństwa i alkoholizmu. Oparte na zachodnioeuropejskich wzorcach towarzystwa wstrzemięźliwości i bractwa trzeźwości powstawały masowo przy parafiach 
rzymskokatolickich już w latach trzydziestych i czterdziestych XIX stulecia. Swą działalność rozwijały nie tylko w nawiązaniu do światopoglądu religijnego, wykorzystywały również szeroki wachlarz przesłanek społecznych i gospodarczych, a wsparcie dla ruchu abstynenckiego dawały też badania naukowe, dobitnie potwierdzające szkodliwość spożywania alkoholu. Upowszechnienie wiedzy na ten temat przyniosło w II połowie stulecia dalszy rozwój działań zmierzających do ograniczenia spożycia, podejmowanych również w coraz większym stopniu przez rodzące się masowe ruchy polityczne. Aktywność w tej dziedzinie przejawiały wszystkie najważniejsze nurty polityczne kształtujące się na przełomie stuleci na ziemiach polskich, a skutkiem tego stała się trwała obecność problematyki antyalkoholowej w ich działalności publicznej, również tej prowadzonej po odzyskaniu niepodległości (Burszta 1951: 95-121; Moczarski 2007: 286-288).

\section{Pierwsze potyczki na polu walki z alkoholizmem}

Odrodzenie państwa przynieść miało znacznie większe niż wcześniej możliwości podejmowania inicjatyw społecznych, także tych antyalkoholowych. Niezmiernie ważnym forum artykułowania popularnych po wojnie poglądów abstynenckich stał się wybrany w styczniu 1919 r. Sejm Ustawodawczy. Wcześniejsza aktywność społeczna działaczy ruchów abstynenckich przełożyła się bowiem na wejście wielu z nich do izby sejmowej. W ławach poselskich zasiadło liczne grono animatorów i członków organizacji trzeźwościowych ze wszystkich trzech zaborów, a najbardziej znani spośród nich, czyli księża Zygmunt Kaczyński, Kazimierz Lutosławski, Wacław Bliziński czy też reprezentująca Narodowe Zjednoczenie Ludowe Maria Moczydłowska, stać się mieli liderami szerokiego, ponadpartyjnego frontu przeciwalkoholowego w pierwszym parlamencie niepodległej Rzeczypospolitej. Ich działania wspierał tradycyjnie stojący za ruchem abstynenckim Kościół katolicki oraz rozbudowane i silnie wpływające na opinię publiczną struktury organizacyjne z powołanym w kwietniu 1919 r. Polskim Towarzystwem Walki z Alkoholizmem „Trzeźwość” na czele (Moczarski 2007: 288).

W nowych warunkach zamierzenia i cele parlamentarnych przedstawicieli ruchów abstynenckich mogły sięgać znacznie dalej niż przed I wojną światową. Miała to już być nie tylko mozolna, wywodząca się $\mathrm{z}$ ideałów pozytywistycznych praca u podstaw, ale również działania na rzecz uchwalenia odpowiednich aktów prawnych ograniczających dostępność i spożycie alkoholu, a nawet, w sprzyjających okolicznościach, 
przeprowadzenie przez Izbę ustawy całkowicie zakazującej sprzedaży i konsumpcji alkoholu na terytorium Rzeczypospolitej, czyli uchwalenie pełnej prohibicji. Sprawa była o tyle ważna, że na ziemiach polskich nie istniało dotąd odpowiednie ustawodawstwo w tym względzie, gdyż wprowadzona w 1877 r. austriacka tzw. ustawa przeciw opilstwu nie była wykonywana, $\mathrm{w}$ zaborze pruskim żadnych regulacji w tej materii nie było, zaś w rosyjskim celem niezwykle skutecznego monopolu spirytusowego była raczej maksymalizacja spożycia i dochodów ze sprzedaży zmonopolizowanej wódki niż walka z alkoholizmem (Grata 2008: 22; Polityka... 1935: 380; Sawicki, Flatau-Kowalska 1958: 90-91).

Działania na rzecz ograniczenia bądź całkowitego nawet zakazu sprzedaży i spożycia napojów alkoholowych toczyły się w Sejmie Ustawodawczym na dwóch równoległych płaszczyznach, a podejmowane w tym kierunku inicjatywy natrafiały nie tylko na opór silnego lobby producentów, ale również Ministerstwa Skarbu, traktującego opodatkowanie konsumpcji spirytusu jako istotne źródło wpływów budżetowych. Stąd też dążenia i inicjatywy antyalkoholowe nierozłącznie związane były z kwestią miejsca opodatkowania spirytusu w budowanym systemie skarbowym państwa, a aktywność przeciwników napojów wyskokowych widoczna była zarówno w czasie debat parlamentarnych poświęconych projektom bezpośrednio związanym z wprowadzaniem ograniczeń w tej materii, jak i przy okazji podejmowania decyzji odnoszących się do regulacji fiskalnych. Można nawet stwierdzić, że obie sfery obecności spraw ,alkoholowych” na forum Izby wzajemnie się uzupełniały, konkurując wyraźnie o kierunek przyjmowanych rozwiązań prawnych.

Dualizm ten widoczny był zwłaszcza w połowie 1919 r., gdy z jednej strony rząd Ignacego Jana Paderewskiego przyjmował i kierował do Sejmu opracowany przez ministra skarbu Stanisława Karpińskiego projekt ustawy o monopolu spirytusowym, a w tym samym niemal czasie kolejne „prohibicyjne” wnioski kierowali do Marszałka Sejmu zwolennicy restrykcyjnych rozwiązań antyalkoholowych. Bardzo liberalny z punktu widzenia zwolenników abstynencji projekt ustawy monopolowej trafił do Sejmu 23 czerwca 1919 r. Mimo koncesjonowania miejsc sprzedaży nie zakładał żadnych ograniczeń w zakresie ich liczby, zakazywał jedynie sprzedaży spirytusu i wyrobów wódczanych dzieciom do lat 16 [sic!], a także ograniczał sprzedaż w niedziele i święta (zakaz handlu alkoholem w naczyniach zamkniętych) oraz określał minimalną odległość punktów wyszynku od świątyń, szkół, sądów i urzędów gminnych na 100 metrów (Druki... 1919: 732).

Co znamienne, przeciw projektowi protestował 13 czerwca na forum Rady Ministrów przedstawiciel Ministerstwa Zdrowia Publicznego, wi- 
ceminister Witold Chodźko, który nie tylko zwrócił uwagę na „,szkodliwe skutki systemu monopolu wódczanego dla zdrowia ludzkiego", ale też opowiedział się za zupełnym zakazem wyszynku. Stanowisko resortu zdrowia poparł minister pracy i opieki społecznej Jerzy Iwanowski, który postulował równoczesne ustawowe uregulowanie form walki z pijaństwem, a także proponował ustalenie maksymalnego i co roku zmniejszającego się kontyngentu sprzedawanego do konsumpcji spirytusu. Nie przeszedł wprawdzie, choć uzyskał cztery głosy poparcia, wniosek Ministerstwa Zdrowia o wydanie ,zupełnego zakazu sprzedaży spirytusu dla konsumpcji” ani inne wnioski szczegółowe ograniczające możliwości handlu spirytusem, jednak przebieg posiedzenia rządu w tej sprawie wyraźnie zapowiadał poważne trudności projektu w Sejmie, jak również znamionował kierunki działań podejmowanych przez jego przeciwników (Protokoty... t. 6: 670-672) ${ }^{2}$.

Już bowiem dziesięć dni wcześniej, czyli 3 czerwca, wpłynął do Sejmu pierwszy z poselskich projektów zakładających wprowadzenie całkowitego zakazu sprzedaży spirytusu monopolowego na cele konsumpcyjne i ograniczenie jego zbytu wyłącznie do celów leczniczych, przemysłowych oraz oświetleniowych. Co istotne, lakoniczny, składający się z trzech krótkich punktów wniosek (raczej rezolucji niż ustawodawczy) sygnowany przez ks. Zygmunta Kaczyńskiego podpisali przedstawiciele różnych klubów parlamentarnych, co stać się miało regułą w przypadku tego typu inicjatyw (trzeci $\mathrm{z}$ artykułów proponowanej uchwały sejmowej wzywał rząd do nieodzownego w wypadku wprowadzenia prohibicji zaostrzenia kar za nielegalną produkcję i sprzedaż wódki) (Druki... 1919: 597).

Wniosek ks. Kaczyńskiego można uznać za sygnał do wzmożonej ofensywy środowisk antyalkoholowych podjętej w związku z prowadzonymi w łonie rządu pracami nad ustawą o monopolu spirytusowym. Drugi z wniosków, księdza Antoniego Ludwiczaka z 10 czerwca, proponował ,ze względu na niebezpieczeństwo grożące krajowi z nadmiernego używania napojów alkoholowych" możliwość nadania gminom prawa wprowadzania w drodze referendum całkowitego zakazu sprzedaży alkoholu. Powołując się na obowiązujące w amerykańskim stanie Massachusetts prawo tzw. „lokaloption”, wnioskodawcy wzywali rząd, by

\footnotetext{
${ }^{2}$ Jedyne ograniczenie sprzedaży wprowadzone do projektu na posiedzeniu rządu dotyczyło zakazu handlu alkoholem w naczyniach zamkniętych w niedziele i święta, upadły natomiast propozycje resortu zdrowia, by zakaz ten rozciągnąc na dni przedświąteczne oraz na sprzedaż wyszynkową, podobny los spotkał poprawkę wprowadzającą nakaz przeznaczania części dochodu z monopolu spirytusowego na cele „zwalczania pijaństwa”.
} 
również w Polsce dać gminom takie uprawnienia, a na dowód ich skuteczności prezentowali znacznie niższe statystyki ubóstwa i przestępczości w miastach, w których zakazy takie weszły w życie (Druki... 1919: 816).

Projekt wprowadzenia zasady samostanowienia gmin w zakresie wprowadzania prohibicji był, co znamienne, najbardziej liberalnym spośród powstających w ówczesnym parlamencie. Kolejne formułowane wnioski zawierały już bowiem, podobnie jak wcześniejszy ks. Kaczyńskiego, propozycje pełnego zakazu sprzedaży i konsumpcji alkoholu w całym kraju, w sposób bezpośredni odnosiły się również do planów monopolowych rządu. Projekt ustawy zakazującej wyszynku i sprzedaży napojów alkoholowych autorstwa Marii Moczydłowskiej trafił do Sejmu na początku lipca, zaś wniosek nagły „o całkowitem zakazaniu w Rzeczypospolitej wyrobu i sprzedaży napojów alkoholowych" podpisany przez ponad 70 ,posłów wszystkich Klubów Poselskich” - w tydzień później, czyli 9 lipca 1919 r. Stało się to zatem jeszcze przed wejściem pod obrady Izby projektu ustawy monopolowej i w sposób oczywisty ukierunkowane było na obalenie rządowych zamiarów w tym względzie. Co więcej, drugi z wniosków wprost zakładał, że „w ustawie dotyczącej monopolu spirytusowego ma być przewidziany całkowity zakaz wyrobu i sprzedaży w Rzeczypospolitej napojów alkoholowych" (Druki... 1919: 740; 1919: 774).

Jedyny w całym okresie międzywojennym kompletny projekt wprowadzenia w Rzeczypospolitej pełnej prohibicji, który trafił pod obrady Komisji Zdrowia Publicznego, zezwalał na objętą monopolem państwa produkcję spirytusu jedynie na cele przemysłowo-techniczne, naukowe i lecznicze. Zakazana miała być natomiast wszelka sprzedaż i podawanie napojów alkoholowych. Za złamanie tego przepisu projekt przewidywał kary więzienia do jednego roku, wysokie grzywny oraz pozbawienie praw wyborczych do Sejmu i gminy na trzy lata. Poza szczegółowym określeniem zasad egzekwowania prohibicji wnioskodawcy zakładali również w art. 10 projektowanej ustawy areszt dla osoby, która $\mathrm{w}$ stanie nietrzeźwym pojawiłaby się $\mathrm{w}$ miejscu publicznym, oraz oddanie takiej osoby jako alkoholika w myśl ustawy o opiece nad psychicznie chorymi do szpitala „w celu przeprowadzenia należytej kuracji”. Równocześnie ustawa miała nałożyć obowiązek donoszenia władzom o przypadkach naruszania jej przepisów, przewidywała również nagrody dla obywateli, którzy przyczyniliby się do wykrycia takich sytuacji, a do jej wykonywania mieli być delegowani, obok organów władzy państwowej, przedstawiciele towarzystw i organizacji zwalczających alkoholizm (Druki... 1919: 740). 
Wśród tak zarysowanych celów środowisk antyalkoholowych zaplanowane na 2 lipca pierwsze czytanie ustawy o monopolu spirytusowym musiało się stać areną otwartego starcia między jego zwolennikami a wrogo nastawionymi do alkoholu i jego sprzedaży reprezentantami koncepcji abstynenckich i prohibicyjnych. Na pierwszej linii frontu stanęła w debacie posłanka Moczydłowska, która podkreślając na wstępie wagę debaty (,sprawa dzisiejszej ustawy wciska się we wszystkie dziedziny życia narodowego"), zgodziła się wprawdzie, że monopol pozornie może dać pewne „podstawy finansowe”, ale ,jednocześnie podcina siły fizyczne i ekonomiczne przez zmniejszenie wydajności pracy, zwiększenie ilości chorych i nawet z punktu finansowego nie wytrzymuje krytyki". Ukazując wszystkie negatywne skutki alkoholizmu, mówczyni dowodziła, że wprowadzenie monopolu może jedynie, podobnie jak wcześniej w Rosji, problemy z nim związane pogłębić. Z drugiej strony ukazywała pozytywne skutki wprowadzanych w różnych krajach (Anglia, państwa skandynawskie) ograniczeń w spożyciu napojów spirytusowych, przypominając o planowanej pełnej prohibicji w tym względzie w Stanach Zjednoczonych (Sprawozdanie... 61: 4-5; A.R. 1919: 1).

W konstatacji swego wystąpienia posłanka Moczydłowska ostrzegła, że jeśli robotnicy i chłopi nie będą trzeźwi, „to mogą przepić Polskę ludową tak, jak olbrzymia część szlachty XVIII wieku przepiła Polskę". Co więcej, uznała, że „tylko ślepy albo zły człowiek, tylko wróg nasz może użyczyć pijaństwu uświęcenia przez monopol", a na zakończenie przedstawiła w imieniu Narodowego Zjednoczenia Ludowego wniosek o przejście Sejmu do porządku dziennego nad projektem ustawy monopolowej i wezwanie Komisji Zdrowia Publicznego do „śpiesznego" przedstawienia odpowiedniego projektu, zgodnego z ideami zawartymi w złożonych już w Sejmie wnioskach w ,przedmiocie wydania ustawy przeciwalkoholowej” (Sprawozdanie... 61: 6).

Sprawy monopolu próbował wprawdzie bronić minister Stanisław Karpiński, który przyznał, że mimo iż był wrogiem tej formy opodatkowania, złożył projekt ustawy monopolowej właśnie po to, by jak najlepiej realizować związane ze spożyciem alkoholu cele społeczne, wskazane w mowie posłanki Moczydłowskiej. Przypominając o znaczeniu fiskalnym spirytusu, minister starał się przedstawić ewentualne korzyści płynące $\mathrm{z}$ wejścia $\mathrm{w}$ życie organizującego cały rynek alkoholowy monopolu, równocześnie zastrzegał, iż ustawa ma charakter tymczasowo jedynie unifikujący zróżnicowany w poszczególnych dzielnicach państwa stan prawny i ma stworzyć podatny grunt do „wygotowania ostatecznej ustawy”. Deklarował również przeznaczanie większych ilości alkoholu na cele niekonsumpcyjne, jednak zwolenników walki o abstynencję spo- 
łeczeństwa nie przekonał. Jedyny bowiem argument mający realizować przywoływane wcześniej cele społeczne stanowić miała ścisła kontrola przez władze monopolowe sprzedaży alkoholu, co trudno było uznać za instrument ograniczający rozmiary spożycia (Sprawozdanie... 61: 6-11).

Szybko wytknął to ministrowi poseł Jan Woźnicki, a generalnie cała debata stała się okazją do wielostronnej krytyki ukierunkowanego fiskalnie projektu, pojawiło się w niej również wiele wątków antyalkoholowych, po raz kolejny potwierdzających znaczenie w Sejmie zwolenników i sympatyków tendencji abstynenckich, a nawet prohibicyjnych. Nie unikano patosu (,nasza zmartwychwstała Polska jeszcze roku nie ma, a my gościmy ją wódką") ani merytorycznych zarzutów o brak odpowiednich rygorów antyalkoholowych w projekcie, jednak mimo powszechnego w Izbie potępienia pijaństwa i alkoholizmu większość posłów nie przychyliła się do wniosku posłanki Moczydłowskiej. Stanowisko takie wynikało $\mathrm{z}$ bardziej realistycznego podejścia do problematyki walki $\mathrm{z}$ alkoholizmem, popartego doświadczeniami innych krajów, które przekonały się, że „zakazy nie prowadzą do niczego”, a problem należy rozwiązywać innymi metodami (ich wypracowanie miała wspomagać Komisja Zdrowia Publicznego Sejmu). Stąd też wniosek o odrzucenie projektu ustawy już w pierwszym czytaniu nie uzyskał poparcia większości posłów, a sprawę skierowano do Komisji Skarbowo-Budżetowej (Sprawozdanie... 61: 11-23).

\section{Projekt ustawy antyalkoholowej}

Było to jednak raczej pyrrusowe zwycięstwo Ministerstwa Skarbu, gdyż projekt na forum Sejmu już nie wrócił, ale też praktyczne niepowodzenie prowadzonego w części kraju monopolu spirytusowego przekreśliło szanse na jego realizację (sam monopol zawieszono w 1921 r.). Powrócić miała natomiast do Sejmu sprawa ustawowej regulacji ograniczeń w sprzedaży i konsumpcji napojów alkoholowych. Złożone bowiem w połowie roku 1919 wnioski postulujące pełną prohibicję trafiły do Komisji Zdrowia Publicznego i stały się podstawą prac nad przygotowaniem ostatecznej wersji projektu tzw. ustawy antyalkoholowej. Komisja nie przychyliła się do zbyt daleko idących propozycji (zdecydował zaledwie jeden głos) i , uznała w chwili obecnej jedynie za wykonalne częściowe ograniczenia w sprzedaży napojów alkoholowych". Mimo tego przedstawiony 3 grudnia projekt ustawy o ograniczeniach w sprzedaży napojów alkoholowych stanowił kolejny ważny krok w działaniach 
w tym względzie, a w artykule 1 proponowanego prawa znalazła się zapowiedź wprowadzenia w przyszłości w całym państwie „ogólnego zakazu produkcji oraz obrotu handlowego wszelkimi zawierającymi alkohol ponad określoną normę produktami płynnymi (napoje wyskokowe) dla celów spożycia" (Druki... 1919: 1233; Polskie... 1922: 102).

Tymczasem jednak projekt zakładał ograniczenia $\mathrm{w}$ handlu napojami zawierającymi powyżej 2,5\% alkoholu oraz całkowity zakaz sprzedaży napojów o mocy powyżej 45\%, przyznając równocześnie związkom komunalnym (gminom wiejskim i miejskim) prawo uchwalania w drodze głosowania powszechnego całkowitego zakazu sprzedaży napojów alkoholowych (do przeprowadzenia takiego referendum wystarczało podpisanie wniosku przez 10\% mieszkańców, którzy ukończyli 21 rok życia). Punkty sprzedaży, których liczba nie mogła być większa niż jeden na 2,5 tys. mieszkańców (tylko połowa z prawem wyszynku), mogły znajdować się w odległości minimum $50 \mathrm{~m}$ od warsztatów fabrycznych zatrudniających ponad 50 pracowników oraz co najmniej $100 \mathrm{~m}$ od budynków szkół, kościołów i zakładów zatrudniających powyżej stu robotników. Zakazywano w projekcie sprzedaży alkoholu młodzieży do lat 18, na kredyt, w bufetach kolejowych i zabudowaniach kolejowych, na obszarze koszar i w sklepach wojskowych, w domach ludowych, w zabudowaniach fabrycznych, w niedziele i święta, a także w miejscowościach, gdzie odbywają się „tłumne zebrania napływowej ludności” (podczas targów, jarmarków, odpustów, pielgrzymek), w których odbywa się pobór lub mobilizacja bądź obchodzone są uroczystości państwowe lub kościelne. Obok wielu ograniczeń projekt zakładał również kary za ich nieprzestrzeganie (grzywny i areszt do trzech miesięcy), a karalne miało być też podawanie w miejscach wyszynku takiej ilości alkoholu gościom, „która doprowadziła ich do stanu nietrzeźwego” (Druki... 1919: 1233).

Poza projektem Komisja zaproponowała Sejmowi osiem rezolucji wzywających rząd do aktywnej propagandy antyalkoholowej, wsparcia samorządów w tym dziele, wprowadzenia problematyki abstynenckiej w programach szkolnych, zmniejszenia ilości ziemniaków przeznaczanych na przerób na spirytus oraz ograniczenia do minimum liczby czynnych gorzelni, wzmożenia walki z nielegalnym gorzelnictwem, ustanowienia zakazu używania alkoholu w armii, a nawet zgłoszenia inicjatywy antyalkoholowej na forum Ligi Narodów oraz opracowania projektu ustawy ,regulującej sprawę odpowiedzialności za opilstwo”. W ten sposób proponowany projekt ustawy oraz związane $\mathrm{z}$ nim postulaty zapisane w rezolucjach stanowiły - mimo czasowej rezygnacji z pełnej prohibicji bardzo rozbudowany katalog działań antyalkoholowych mających na celu 
stworzenie prawnych podstaw ograniczenia spożycia alkoholu i podniesienia poziomu trzeźwości w społeczeństwie (Druki... 1919: 1233).

Dotyczące projektu sprawozdanie Komisji Zdrowia Publicznego symbolicznie podsumowywało działania na rzecz ograniczeń w sprzedaży i konsumpcji alkoholu w pierwszym roku istnienia Sejmu Ustawodawczego, stanowiąc równocześnie obiecującą z punktu widzenia zwolenników daleko idących obostrzeń w tym względzie zapowiedź tego, co wydarzyć się miało w Izbie w roku następnym. Nie udało się wprawdzie zaproponować wzorem Stanów Zjednoczonych pełnej prohibicji, jednak projekt restrykcyjnej ustawy antyalkoholowej był już gotowy, a duże poparcie dla szeroko rozumianych postulatów trzeźwościowych w Sejmie dawało aktywistom ruchów abstynenckich nadzieję na przeprowadzenie przez Izbę proponowanych regulacji prawnych już w roku 1920.

\section{Przyjęcie ustawy z 23 kwietnia 1920 r.}

Zanim projekt ustawy trafił pod obrady Izby, nowy, utworzony w grudniu 1919 r. gabinet Leopolda Skulskiego na posiedzeniu 8 stycznia 1920 r. „po dłuższej dyskusji” zdecydował się zwrócić do Marszałka Sejmu o ponowne skierowanie projektu do komisji, by mogły tam zostać wprowadzone doń poprawki zaproponowane przez rząd (część z przedstawionych uprzednio rozwiązań uznano za niewykonalne). Komisja większość poprawek wprawdzie przyjęła (z artykułu 1 projektu usunięto na przykład zapowiedź wprowadzenia w przyszłości pełnego zakazu produkcji i sprzedaży alkoholu na cele konsumpcyjne), utrzymała jednak kwestionowany przez rząd zakaz sprzedaży alkoholu w niedziele i święta oraz zakaz sprzedaży i podawania napojów alkoholowych w bufetach kolejowych i zabudowaniach koszarowych (Protokoty ... t. 9: 25; Druki... 1920: 1623).

Mimo poprawek wymowa przedstawionego Izbie 20 kwietnia $1920 \mathrm{r}$. projektu pozostała niezmieniona, a jego celem miało być znaczące ograniczenie dostępu do alkoholu i jego spożywania. Mówiła o tym przedstawiająca założenia nowego prawa posłanka Maria Moczydłowska, szeroko uzasadniając konieczność jego wprowadzenia w życie względami zdrowotnymi, kulturowymi, patriotycznymi, historycznymi, religijnymi czy wojskowymi. W argumentacji odwoływała się do wielu autorytetów, m.in. Adama Mickiewicza. Za zdecydowanie najważniejszy w ustawie uznała przepis dający możliwość uchwalania lokalnych prohibicji w gminach i powiatach, który jej zdaniem miał doprowadzić do „oddolnego" wejścia w życie bezwzględnego zakazu handlu i spożycia w całym kraju (Sprawozdanie... 138: 27-32). 
Projekt spotkał się z przychylnym przyjęciem posłów, którzy zgodnie podkreślali jego znaczenie dla zdrowia mieszkańców i powodzenia państwa, choć część mówców wyrażała niedosyt z powodu złagodzenia zaproponowanych ograniczeń; wielu domagało się wprowadzenia pełnego zakazu sprzedaży i spożycia alkoholu. Przyjęcie ustawy powszechnie uznawane była za oczywiste, co najlepiej bodaj wyraził poseł Józef Putek, który stwierdził, iż „sprawa walki z karczmą i alkoholizmem jest tak prosta $\mathrm{i}$ jasna, że dalszego motywowania $\mathrm{z}$ naszej strony nie wymaga". Wśród przywoływanych w debacie argumentów znajdowało się wiele odniesień do propinacyjnej przeszłości ziem polskich czy też wspominanego z niechęcią rosyjskiego ,pijanego budżetu", w dużej mierze opartego na dochodach $\mathrm{z}$ monopolu wódczanego (Sprawozdanie... 138: 34-59).

Mimo szerokiego poparcia dla ustawy z części wypowiedzi wyraźnie przebijał pesymizm co do przewidywanej skuteczności procedowanego prawa. $Z$ drugiej strony poseł Herman Diamand konstatował, iż „w tych czasach Sejm nie może obojętnie zachować się wobec konsumpcji alkoholu wysokostopniowego i to, co w danych warunkach jest możliwe, zrobić musi". Co istotne, uczestnicy debaty, z niewielkimi wyjątkami (posłowie Antoni Rząd, Aleksander Thomas, Stanisław Chaniewski), niemalże pomijali płaszczyznę ekonomiczną. Wątpliwości w tym względzie zgłaszane od miesięcy przez silne lobby przemysłu spirytusowego były a priori odrzucane, podobnie jak powszechnie znane korzyści fiskalne z opodatkowania alkoholu. Posłanka Moczydłowska z wielką wiarą deklarowała nawet, iż ,przez walkę z alkoholem, da Bóg, wzmocnią się siła podatkowa Państwa Polskiego, wzmocnią się siły fizyczne i duchowe narodu polskiego". Nie wszyscy jednak ten optymizm podzielali, a najlepszym bodaj wyrazicielem sceptycyzmu w tej kwestii był poseł Stanisław Chaniewski, który popierając szczytne cele projektu, przypominał jednak o rozmiarach przemysłu spirytusowego i tysiącach w nich pracujących robotników, jak też ostrzegał, że drogą najlepszej nawet ustawy „umoralnić narodu nie da się z dnia na dzień”, za pewnik uznawał zaś rozkwit tajnego gorzelnictwa w przypadku ewentualnego zakazu produkcji legalnej. Podobnych argumentów użył również poseł Thomas - zgłosił on wniosek o przejście nad projektem do porządku dziennego (Sprawozdanie... 138: 34; 139: 5-17).

Stanowczo nań zareagowała posłanka Moczydłowska, której było nawet „niezmiernie” przykro, „że w ogóle taki wniosek w pierwszym Polskim Sejmie odradzającej się Ojczyzny mógł być zgłoszony”. Mimo tego „uchybienia” z satysfakcją podsumowała jednak rozłożoną na dwa posiedzenia Izby debatę, w której wszyscy uczestnicy, z wyjątkiem jed- 
nego (,wierzę, że będzie głosem wołającego na puszczy”), dowiedli jej zdaniem, iż „Sejm Polski wypowiedział się za energiczną walką z alkoholizmem". Wyraziła też nadzieję, że ustawa może wreszcie wpłynie na to, że „przestaniemy pić wódkę wówczas, kiedy się człowiek rodzi i umiera, kiedy są jego imieniny, z okazji złej przygody lub niespodziewanego szczęścia”. Z „bólem serca” wypowiedziała się przeciw zgłoszonemu przez posła Samuela Hirszhorna wnioskowi o całkowity zakaz sprzedaży spirytusu, gdyż przeciwko takiemu rozwiązaniu już wcześniej, po długich naradach, wypowiedziała się Komisja Zdrowia Publicznego (Sprawozdanie... 139: 17-18).

Po wprowadzeniu kilku drobnych poprawek ustawa z dnia 23 kwietnia 1920 r. o ograniczeniach w sprzedaży napojów alkoholowych została przyjęta $\mathrm{w}$ drugim czytaniu i trzecim czytaniu. Izba zaakceptowała również zgłoszone przez komisję oraz $\mathrm{w}$ trakcie debaty rezolucje wzywające rząd do podjęcia działań mających na celu ograniczenie produkcji i sprzedaży alkoholu w kraju, a także wsparcie dla eksportu spirytusu (Sprawozdanie... 139: 18-23). W ten sposób Sejm Ustawodawczy częściowo przynajmniej zrealizował widoczne od początku jego istnienia dążenie do ustawowego ograniczenia spożycia alkoholu, dając równocześnie samorządom (i aktywistom antyalkoholowym) do ręki instrument umożliwiający przyjmowanie lokalnych przepisów o pełnej prohibicji. Ustawa z 23 kwietnia 1920 r. wchodziła w życie z dniem przyjęcia, a celem jej wykonania wydane zostały dwa rozporządzenia Ministra Spraw Wewnętrznych (z 3 marca 1920 r.) oraz Ministra Zdrowia Publicznego (z 16 września 1920 r.) (DzU 1920: 37/210; 71/487; 98/650; Głodowski 2006: 128-129). W marcu roku 1922 przepisy ustawy rozciągnięte zostały na tereny województw nowogródzkiego, poleskiego, wołyńskiego i wschodnich powiatów białostockiego, zaś we wrześniu tego roku zaczęły obowiązywać również na obszarze Ziemi Wileńskiej (DzU 1922: 34/287; 84/757).

\section{Próby „stępienia ostrza” ustawy antyalkoholowej}

Wyraźnie afirmatywny dla przyjętej 23 kwietnia 1920 r. ustawy stosunek parlamentarzystów nie oznaczał końca debaty na temat kształtu przepisów antyalkoholowych w Sejmie Ustawodawczym, zwłaszcza że w wielu miejscach były one niekorzystne dla środowisk gospodarczych związanych zarówno z produkcją, jak i handlem wyrobami alkoholowymi. Szczególnie problematyczne były przepisy nakazujące redukcję miejsc sprzedaży detalicznej do 1 stycznia 1921 r. Zgodnie z ustawą 
jedno takie miejsce mogło przypadać na najwyżej 2,5 tys. mieszkańców, a tylko połowa takich punktów mogła być połączona z wyszynkiem (jeden punkt na 5 tys. mieszkańców). Widmo likwidacji blisko połowy spośród istniejących wtedy około 20 tys. miejsc sprzedaży kazało Radzie Stowarzyszenia Kupców Polskich od początku domagać się uchylenia art. 6 ustawy. Jego wykonanie zamiast zmniejszyć konsumpcję powodowałoby „przymusową likwidację i ruinę całego szeregu poważnych przedsiębiorstw bez żadnego pożytku dla Skarbu, a z wielkim uszczerbkiem materialnym i moralnym dla szeregu firm spełniających wszystkie obowiązki nałożone przez Państwo i Społeczeństwo" (Nowy... 1920: 338-339).

Zagrożenie podstaw bytu osób utrzymujących się z tego typu działalności handlowej szybko znalazło oddźwięk w inicjatywach mających na celu zmianę obowiązującego stanu prawnego. Wykreowany jeszcze w trakcie kwietniowej debaty na wroga przepisów antyalkoholowych Aleksander Thomas wraz z grupą kilkunastu posłów złożył 26 listopada 1920 r. wniosek o skreślenie w ustawie niektórych artykułów nastawionych na ograniczenie sprzedaży napojów alkoholowych. Pierwszym miał być przepis nakazujący redukcję liczby miejsc sprzedaży i wyszynku, co zdaniem wnioskodawców miało skutkować utratą środków utrzymania przez 60 tys. rodzin restauratorów, kelnerów i służby restauracyjnej. Poza tym domagano się zniesienia zakazu sprzedaży alkoholu w bufetach kolejowych (miał być szkodliwy dla... zdrowia podróżnych marznących w nieopalanych pociągach) oraz bufetach wojskowych (,wywołuje słuszne niezadowolenie u żołnierzy, którzy przelewając krew za Ojczyznę, nie chcą być przez tę Ojczyznę traktowani jako nieletnie dzieci"). Co więcej, wnioskodawcy zaproponowali również Izbie zniesienie zakazu sprzedaży alkoholu w niedziele i święta oraz w dniach targów i jarmarków jako z zasady niemożliwego do realnego wyegzekwowania (Druki... 1920: 2354).

Wprowadzone ustawą ograniczenia działalności gospodarczej stały się również przedmiotem zainteresowania gabinetu Wincentego Witosa, który 4 stycznia 1921 r. przyjął stanowisko w sprawie niezbędnych zmian w ustawie zwanej antyalkoholową. Znamienne, że na posiedzeniu rządu przyjęto tylko jedną poprawkę, zaproponowaną przez resort przemysłu i handlu, zwiększającą dopuszczalną moc sprzedawanych produktów do $60 \%$ zawartości czystego alkoholu, przygotowanie pozostałych zlecając odpowiedzialnemu za dochody budżetu Ministerstwu Skarbu. Taki obrót spraw zwiastował latwe do przewidzenia wnioski ustawodawcze (Protokoly ... t. 13: 1-2).

Przedstawiony przez resort skarbu projekt noweli trafił do Sejmu w połowie miesiąca. U jego podstaw leżało założenie, iż ustawa w spo- 
sób znaczący utrudniła produkcję napojów alkoholowych i handel nimi, a ograniczenia te „wywarły bardzo ujemny wpływ na dochód Skarbu Państwa z podatków spożywczych od napojów alkoholowych". W związku z tym wniosek zawierał propozycje ważnych zmian w ustawie mających ten wpływ neutralizować, a zatem znacząco osłabiających praktyczny wymiar ustawy z 23 kwietnia. Przede wszystkim znalazło się $\mathrm{w}$ nim przesunięcie aż o dziesięć lat (do 1 stycznia 1931 r.) terminu zredukowania liczby koncesji dożywotnich na sprzedaż i wyszynk alkoholu w b. zaborze austriackim. Zmianą fundamentalną miało być również podniesienie z 2,5\% do $8 \% \mathrm{za}-$ wartości alkoholu w napojach zwolnionych od ograniczeń sprzedaży, co oznaczać miało wejście do tej kategorii piwa. Wreszcie zgodnie ze wspomnianą już sugestią Ministerstwa Przemysłu i Handlu zakładano zwiększenie maksymalnej zawartości alkoholu w sprzedawanych trunkach z $45 \%$ do $60 \%$, ważne zarówno dla zakładów tradycyjnie takie napoje wytwarzających (fabryk koniaków i rumów), jak i dla Skarbu, który od maja 1920 r. za taki właśnie wysokoprocentowy alkohol oprócz opłaty monopolowej część należności pobierał w złocie lub srebrze (monetach lub kruszcu) (Druki... 1921: 2396).

Zgłoszony przez resort skarbu projekt noweli stał się przedmiotem obrad trzech komisji sejmowych: skarbowo-budżetowej, przemysłowo-handlowej oraz zdrowia publicznego, a jego losy po raz kolejny dowiodły siły środowisk abstynenckich w Sejmie Ustawodawczym. Po wielu miesiącach i siedmiu posiedzeniach komisje dopiero w październiku 1921 r. przygotowały swoje sprawozdanie zawierające propozycje zmian w ustawie, a na forum Izby trafiło ono, po uprzednim odroczeniu, 17 stycznia 1922 r. Co istotne, przedstawiona posłom propozycja nijak się miała do wniosku Ministerstwa Skarbu i nastawiona była raczej na dalsze zaostrzenie przepisów niż ich liberalizację. Nie było w niej mowy o sprzedaży napojów zawierających powyżej $45 \%$ alkoholu, wyłączenie z ograniczeń dotyczyć miało jedynie napojów o mocy poniżej $4 \%$, co de facto utrzymywało niepodleganie temu wyłączeniu większości gatunków piwa, zaś odroczenie procesu redukcji liczby koncesji i likwidacji punktów sprzedażnych mogło być zastosowane jedynie w nadzwyczajnych, szczególnie uzasadnionych przypadkach i tylko do 1 stycznia $1923 \mathrm{r}$. Co więcej, przedstawiona Sejmowi przez komisje propozycja zawierała zakaz sprzedaży alkoholu osobom nieletnim do ukończenia 21 roku życia (w ustawie z 23 kwietnia cezura ta wynosiła 18 lat), wpisano również do projektu sankcje za budzące zgorszenie zachowania pod wpływem alkoholu, jak też doprowadzenie osoby nieletniej do stanu nietrzeźwości (Druki... 1921: 3062; Sprawozdanie... 259: 16; 278: 40). 
W ten sposób próby złagodzenia przepisów ustawy z 23 kwietnia 1920 r. przyniosły skutek odwrotny od zamierzonego, czego potwierdzeniem stały się prace Sejmu w tym zakresie. Stanowisko komisji przedstawił poseł Zenon Lewandowski, który wprost oskarżył rząd o niewykonywanie ustawy. Mówiąc o dążeniu do położenia tamy nieszczęściu, jakim było spożywanie napojów alkoholowych, stwierdził, iż „Sejm zrobił swoje, lecz niestety Rząd nie dorósł do tego zadania, jak i w wielu innych przypadkach i zignorował postanowienie Sejmu". Sam zaś projekt złożony przez ministra skarbu Jana Kantego Steczkowskiego uznał za nastawiony jedynie na uzyskiwanie dochodów budżetowych z pijaństwa i niegodny wskutek tego nowoczesnych państw. W związku z tym komisje przygotowały projekt mający na celu wzmocnić wydźwięk obowiązującej ustawy już w warstwie nazewnictwa. Nowa wersja jej tytułu miała obejmować ograniczenie nie tylko sprzedaży, ale również spożycia, gdyż taki był przecież zasadniczy cel przyświecający od początku jej inicjatorom. W wystąpieniu pojawił się również wątek antyżydowski, opierający się na stereotypie Żyda-szynkarza, ale także wykorzystujący stanowisko jednej z gmin żydowskich opowiadającej się za utrzymaniem dotychczasowych zasad prowadzenia wyszynku. Jak perorował Lewandowski: ,jest to głos gminy żydowskiej w Sierpcu, a więc głos oficjalny żydowski. Stąd nietrudno wywnioskować, komu oprócz szynkarzy, zależy na rozpijaniu naszego ludu" (Sprawozdanie... 278: 43-46).

W kontekście przekonania, iż ,tylko ludzie źli i wrogowie Polski mogą się sprzeciwiać wyrwaniu ludu z pęt pijaństwa", rząd winien zdaniem sprawozdawcy przystąpić do wykonywania ustawy i „dopiero wówczas, gdy ustawa będzie w praktyce czas jakiś wykonywana, gdy się okażą braki, będzie racja poczynienia zmian". Przy tak zarysowanym polu dyskusji w sposób oczywisty poszła ona nie tylko w kierunku potwierdzania dbałości o zdrowie i dobrobyt „ludu”, ale także rezygnacji z jakichkolwiek ustępstw w stosunku do zwolenników liberalizacji przepisów. Efektem tego stała się poprawka ks. Lutosławskiego przywracająca granicę 2,5\% zawartości alkoholu dla napojów niepodlegających obostrzeniom. Jak dowodził, ,zwalnianie od ograniczenia do $4 \%$ pociągnie za sobą fatalne jedno następstwo, że otworzą się szerokie wrota dla handlu fałszowanymi winami. Istnieje cały przemysł w miasteczkach, zwłaszcza w Małopolsce, przemysł głównie żydowski, który się trudni fabrykowaniem win, to jest trunek, który ma właśnie między 2,5 a $4 \%$ alkoholu". Z drugiej strony przesunięcie tej granicy oznaczałoby podniesienie mocy zwykłego piwa, a także straty dla Skarbu, który utracić miał kontrolę nad jego produkcją. W toku debaty nie tylko powszechnie krytykowano rząd za niewykonywanie ustawy z 23 kwietnia, ale także pod 
pręgierzem krytyki stawiano posłów podpisanych pod wnioskiem o nowelizację złożonym w listopadzie 1920 r., których nazwiska poseł Józef Putek odczytał, ,aby na wieki w protokole stenograficznym były zanotowane". Poseł Thomas, jako napiętnowany, bronił się, że widzi inną drogę walki $\mathrm{z}$ alkoholizmem, jednak jego merytoryczne argumenty w panującej w Izbie gorącej atmosferze nie trafiały do przekonania parlamentarzystów (Sprawozdanie... 278: 46-59).

Mimo tego występujący w imieniu przemysłu spirytusowego i gospodniego przeciwnicy ustawy, a tym bardziej jej zaostrzenia, nie składali broni. Korzystając z nieprawidłowości proceduralnych (poseł Rosset mówił nawet o fałszowaniu protokołów z zebrań komisji), ponownie doprowadzili do odroczenia tym razem trzeciego już czytania, które miało się odbyć 24 stycznia 1922 r. Nie na wiele się to jednak zdało, czego potwierdzeniem stało się trzecie czytanie, do którego ostatecznie doszło 27 stycznia. Występujący w imieniu Związku Ludowo-Narodowego poseł Bolesław Wróblewski próbował wprowadzić jeszcze dwie poprawki łagodzące prawo antyalkoholowe. Pierwsza miała dać możliwość utrzymania koncesji dożywotnich w Galicji do końca roku 1925, a nie 1922, natomiast druga zezwolić na sprzedaż alkoholu w bufetach kolejowych. Obie poprawki zostały przez większość sejmową odrzucone, a ustawę tego dnia $\mathrm{w}$ trzecim czytaniu przyjęto $\mathrm{w}$ wersji skrajnie odmiennej od postulowanej przez rząd, który, co po raz kolejny powtórzył Stanisław Głąbiński, bezprawnie do tej pory wstrzymywał jej wykonanie (Sprawozdanie... 280: 19-20; 281: 4-7).

W ten sposób po ponad roku procedowania nowela ustawy z 23 kwietnia 1920 r. została przyjęta, a wprowadzone w niej zmiany przyniosły dalsze ograniczenia w sprzedaży napojów alkoholowych mające na celu zmniejszenie ich spożycia. Znowelizowany tekst ustawy z dnia 23 kwietnia 1920 r. o ograniczeniach w sprzedaży i spożyciu napojów alkoholowych został opublikowany rozporządzeniem ministra zdrowia publicznego Witolda Chodźki z 10 kwietnia 1922 r., zaś przepisy wykonawcze wydane zostały w porozumieniu z ministrami spraw wewnętrznych i skarbu 2 czerwca tego roku (częściowo znowelizowano je 25 lipca 1922 r.) (DzU 1922: 12/104; 35/299; 51/462; 82/728).

\section{Uwagi końcowe}

Problem nadania walce $\mathrm{z}$ alkoholizmem cech planowej, przemyślanej i skutecznej polityki państwa znalazł w Sejmie Ustawodawczym wielu zwolenników. Mimo bowiem, że nie udało się przeforsować popu- 
larnej po zakończeniu wielkiej wojny nie tylko w Polsce idei całkowitego zakazu sprzedaży napojów alkoholowych, przyjęte drogą ustawową rozwiązania prawne były stosunkowo restrykcyjne i dawały adherentom prohibicji nadzieję na stopniowe jej wprowadzanie w kolejnych częściach kraju. W toku zabiegów o wprowadzenie ustawowych ograniczeń produkcji, handlu i spożycia alkoholu bardzo wyraźnie zarysował się konflikt między aktywistami tak akurat rozumianej walki z alkoholizmem a rządem, zwłaszcza Ministerstwem Skarbu. Ścierały się w nim słuszne ze wszech miar idee $\mathrm{z}$ interesem budżetu państwa, dla którego wpływy z opodatkowania sprzedaży alkoholu pozostawały ważnym elementem dochodu ${ }^{3}$.

W starciu tym zdecydowanie zwyciężyli zwolennicy ograniczeń w sprzedaży alkoholu, z drugiej jednak strony ich zwycięstwo nie przełożyło się na praktykę, a ustawa z 23 kwietnia 1920 r. nigdy, głównie ze względów fiskalnych, nie została w pełni zaimplementowana. Najlepszym tego przykładem stał się przepis nakazujący redukcję miejsc sprzedaży alkoholu do jednego na 2,5 tys. mieszkańców. Oznaczałoby to bowiem ograniczenie liczby tych punktów z około 20 tys. działających w kraju do zaledwie około 11,5 tys. Tak się jednak nie stało, a liczba miejsc sprzedaży na poziomie właśnie 20 tys. utrzymywała się w kolejnych latach (jeden taki punkt przypadał w roku 1928 na 1,4 tys. mieszkańców). Potwierdzeniem akceptacji dla stanu faktycznego stała się nowa ustawa o ograniczeniach w sprzedaży, podawaniu i spożyciu napojów alkoholowych przyjęta przez Sejm 21 marca 1931 r. i dostosowująca stan prawny do rzeczywistości (DzU 1931: 51/423; Rocznik... 1929: 494; Grata 2009: 263).

Nawet pozorne sukcesy wynikające $\mathrm{z}$ obowiązywania ustawy z 23 kwietnia 1920 r. niekoniecznie nimi były, czego dowodem nie do końca zgodny $\mathrm{z}$ oczekiwaniami twórców regulacji sposób realizacji przepisów zezwalających na wprowadzanie przez gminy całkowitego zakazu sprzedaży napojów zawierających powyżej 2,5\% alkoholu. Do 1930 r. głosowań dotyczących tego typu wniosków przeprowadzono w całym kraju 629 i w większości zakończyły się one wynikiem pozytywnym. Ze względu na zastrzeżenia ze strony władz administracyjnych tylko w 227 gminach prohibicja faktycznie weszła w życie. Z drugiej jednak strony aż $2 / 3$ takich gmin znajdowało się na terenach zdomino-

${ }^{3}$ Wyraźnie zmarginalizowane w tym sporze pozostawały interesy środowisk gospodarczych z założenia niemających moralnego prawa domagać się ochrony swych płynących ze spożycia alkoholu zysków.

${ }^{4}$ Ustawa zezwalała na utrzymywanie 20 tys. miejsc sprzedaży alkoholu, w tym aż 3/4 stanowić mogły lokale z wyszynkiem. 
wanych przez żywioł ukraiński województw południowo-wschodnich, co potwierdzać mogło tezę o politycznym w dużej mierze charakterze przeprowadzanych głosowań (równocześnie na terenach tych wykrywano dużo przypadków nielegalnego gorzelnictwa). Ten z gruntu niekorzystny dla państwa proceder ukróciła dopiero nowa ustawa przeciwalkoholowa z roku 1931, która ustaliła próg minimalnej frekwencji w trakcie głosowań na poziomie połowy uprawnionych, zaś prawo do wprowadzania lokalnych przepisów prohibicyjnych zniosło ostatecznie rozporządzenie Prezydenta z 24 października 1934 r., co w kontekście doświadczeń własnych oraz obcych w żaden sposób dziwić już wtedy nie mogło (DzU 1931: 51/423; 1934: 96/863; Rocznik... 1930: 485) .

Wspomniana wyżej ustawa o ograniczeniach w sprzedaży, podawaniu i spożyciu napojów alkoholowych (przeciwalkoholowa) z 21 marca 1931 r. stała się potwierdzeniem niepowodzenia twórców tzw. ustawy antyalkoholowej. Oznaczała oficjalny zwrot ku pragmatyzmowi w tej sferze życia społecznego i faktyczny demontaż zbudowanej w Sejmie Ustawodawczym przez zwolenników walki z alkoholizmem konstrukcji mającej na celu znaczące ograniczenie sprzedaży alkoholu w Polsce. Dawał on o sobie zresztą znać już wcześniej w nie do końca zgodnych z prawem działaniach kolejnych rządów, po części ignorujących ustawowe wszak rozwiązania przyjęte przez pełnych optymizmu w tym względzie posłów Sejmu Ustawodawczego (Kaczyński 1937: 41-43).

$\mathrm{Z}$ drugiej jednak strony trudno uznać, że ponieśli oni porażkę w tej walce. Co więcej, ich mimowolnym sprzymierzeńcem okazało się tak nastawione na zyski z opodatkowania alkoholu Ministerstwo Skarbu. Jego przesiąknięte fiskalizmem działania doprowadziły bowiem do dramatycznego spadku konsumpcji (przynajmniej tej oficjalnej) nie tylko wyrobów spirytusowych, ale także wina i piwa. Dość powiedzieć, że spożycie napojów spirytusowych zmniejszyło się z nieco ponad 2 litrów per capita w roku 1924 do poniżej 1 litra w dekadę później, czyli o ponad połowę, konsumpcja wina spadła aż o $70 \%$, a piwa o $60 \%$ (Grata 2002: 197; Grata 2015: 157-158). Można zatem skonstatować, że największe sukcesy w zwalczaniu alkoholizmu w międzywojennej Polsce odnieśli nie tak aktywni w Sejmie Ustawodawczym członkowie ruchów abstynenckich, lecz wytrwale dążący do wzrostu dochodów z konsumpcji napojów wyskokowych resort skarbu...

${ }^{5}$ Rozporządzenie z 1934 r. nie przez przypadek dotyczyło „,zmiany przepisów o monopolu spirytusowym i o sprzedaży napojów alkoholowych". Było bowiem potwierdzeniem ścisłego związku rynku spirytusowego z interesem Skarbu Państwa i funkcjonującym w jego ramach od 1925 r. Państwowym Monopolem Spirytusowym. 


\section{Literatura}

A.R., 1919, Wielka reforma, „Czas”, nr 177.

Archiwum Akt Nowych, Protokoty posiedzeń Rady Ministrów 1918-1937, t. 6, 9, 13 (cyt. Protokoly...).

Besala J., 2017, Alkoholowe dzieje Polski. Czasy rozbiorów i powstań, Poznań.

Burszta J., 1951, Spoleczeństwo i karczma. Propinacja, karczma i sprawa alkoholizmu w spoleczeństwie polskim XIX wieku, Warszawa.

Druki Sejmowe, Sejm Ustawodawczy (SU), 1919, druk nr 597, Wniosek nagty ks. Kaczyńskiego i tow. $w$ sprawie ograniczenia sprzedaży spirytusu monopolowego wytacznie dla celów leczniczych, przemystowych $i$ oświetlenia z 3 czerwca.

Druki Sejmowe, SU, 1919, druk 732, Projekt ustawy $w$ przedmiocie zaprowadzenia Monopolu Spirytusowego na obszarze Państwa Polskiego z 23 czerwca.

Druki Sejmowe, SU, 1919, druk nr 740, Wniosek nagly pos. Marii Moczydłowskiej i tow. $w$ sprawie projektu ustawy o zupełnym zakazie wyrobów $i$ sprzedaży napojów alkoholowych z 30 czerwca.

Druki Sejmowe, SU, 1919, druk nr 774, Wniosek nagły postów X. K. Lutostawskiego, Balickiej, Falkowskiego, A. Cieśli, Moczydłowskiej, Woźnickiego, Lakoty, X. Dachowskiego, Starowieyskiego i 70 innych posłów wszystkich Klubów Poselskich o catkowitem zakazaniu w Rzeczypospolitej wyrobu i sprzedaży napojów alkoholowych z 9 lipca.

Druki Sejmowe, SU, 1919, druk nr 816, Wniosek posta ks. Ludwiczaka i in. w sprawie wydawania ustawy o wyszynkach z 10 czerwca.

Druki Sejmowe, SU, 1919, druk nr 1233, Sprawozdanie Komisji Zdrowia Publicznego o wnioskach naglych: a) ks. Kaczyńskiego i tow. w sprawie ograniczania sprzedaży spirytusu monopolowego dla celów leczniczych, przemystowych $i$ oświetlenia (druk $n r$ 597); b) posta Moczydlowskiej i tow. $w$ sprawie projektu ustawy o zupetnym zakazie wyrobu i sprzedaży napojów alkoholowych (druk $n r$ 740); c) ks. Lutosławskiego i tow. o calkowitem zakazaniu w Rzeczypospolitej wyrobu i sprzedaży napojów alkoholowych (druk $n r$ 774) z 3 grudnia.

Druki Sejmowe, SU, 1920, druk nr 1623, Sprawozdanie dodatkowe Komisji Zdrowia Publicznego o wnioskach nagłych: a) ks. Kaczyńskiego i tow. w sprawie ograniczania sprzedaży spirytusu monopolowego dla celów leczniczych, przemystowych i oświetlenia (druk nr 597); b) posła Moczydlowskiej i tow. w sprawie projektu ustawy o zupetnym zakazie wyrobu i sprzedaży napojów alkoholowych (druk $n r$ 740); c) ks. Lutostawskiego i tow. o catkowitem zakazaniu w Rzeczypospolitej wyrobu i sprzedaży napojów alkoholowych (druk nr 774) z dnia 17 marca.

Druki Sejmowe, SU, 1920, druk 2354, Wniosek posłów Aleksandra Thomasa, Bednarczyka $i$ innych $w$ sprawie skreślenia niektórych artykułów ustawy z dnia 23 IV $1920 \mathrm{r}$. o ograniczeniach $w$ sprzedaży napojów alkoholowych z 26 listopada.

Druki Sejmowe, SU, 1921, druk 2396, Projekt noweli do ustawy o ograniczeniach w sprzedaży napojów alkoholowych z 15 stycznia.

Druki Sejmowe, SU, 1921, druk 3062, Sprawozdanie komisji: skarbowo-budzetowej, przemystowo-handlowej $i$ zdrowia publicznego $w$ przedmiocie projektu noweli Ministra Skarbu z dnia 15 I 1921 r. dotyczacej ustawy o ograniczeniu w sprzedaży napojów alkoholowych z dnia 23 IV $1920 r$.

Dziennik Ustaw (DzU) 1920, 1922, 1931, 1934.

Głodowski B., 2006, Polityka ustawodawcza państwa polskiego wobec kwestii alkoholowej w II Rzeczypospolitej [w:] Z dziejów kultury Pomorza XVIII-XX wieku, t. III, red. J. Borzyszkowski, C. Obracht-Prondzyński, Gdańsk. 
Grata P., 2002, Przemyst gorzelniczy w II Rzeczypospolitej, Rzeszów.

Grata P., 2008, Miejsce monopoli skarbowych $w$ reformie stabilizacyjnej Wtadystawa Grabskiego (1923-1925), Rzeszów.

Grata P., 2009, Monopole skarbowe w polityce podatkowej Drugiej Rzeczypospolitej, Rzeszów.

Grata P., 2015, Podatki pośrednie w Drugiej Rzeczypospolitej, „Studia Historica Gedanensia", T. VI.

Kaczyński R., 1937, Polskie ustawodawstwo w walce z alkoholizmem, „Opiekun Społeczny", nr 12.

Moczarski K.D., 2007, Historia alkoholizmu i walka z nim [w:] W trosce o trzeźwość Narodu. Sylwetki najwybitniejszych działaczy trzeźwościowych XIX i XX wieku oraz antologia ich pism, t. IV, red. M.P. Romaniuk, Warszawa.

Nowy zamach, 1920, „Tygodnik Handlowy”, nr 24.

Polityka społeczna państwa polskiego, 1935, Warszawa 1935.

Polskie ustawodawstwo przeciwalkoholowe, 1922, „Świt. Miesięcznik Poświęcony Walce z Alkoholizmem”, nr 224.

Rocznik Statystyki Rzeczypospolitej Polskiej 1929, 1930.

Rożenowa H., 1961, Produkcja wódki i sprawa pijaństwa w Królestwie Polskim 18151863, Warszawa.

Sawicki J., Flatau-Kowalska A., 1958, Alkohol w prawie karnym, Warszawa.

Sprawozdanie stenograficzne z 61 pos. Sejmu Ustawodawczego z 2 lipca 1919 r.

Sprawozdanie stenograficzne z 138 pos. Sejmu Ustawodawczego z 20 kwietnia 1920 r.

Sprawozdanie stenograficzne z 139 pos. Sejmu Ustawodawczego z 23 kwietnia 1920 r.

Sprawozdanie stenograficzne z 259 pos. Sejmu Ustawodawczego z 8 listopada $1921 \mathrm{r}$.

Sprawozdanie stenograficzne z 278 pos. Sejmu Ustawodawczego z 17 stycznia 1922 r.

Sprawozdanie stenograficzne z 280 pos. Sejmu Ustawodawczego z 24 stycznia 1922 r.

Sprawozdanie stenograficzne z 281 pos. Sejmu Ustawodawczego z 27 stycznia 1922 r.

\section{The anti-alcohol crusade of the Legislative Sejm and its effects 1919-1922}

\section{Abstract}

The struggle against alcoholism was an essential element of social policy during the Second Republic, and at its heart were the creation of appropriate legal norms. The biggest contribution in this field was made by the Legislative Sejm, whose work became the first Polish anti-alcohol laws. The matter of the propagation of abstinence and the restriction of the consumption of strong alcohols never met with as much sympathy or understanding as it did during the term Legislative Sejm, whose membership, social structure and inclination towards temperance resulted in a clear prohibitionist tendency on the question of the consumption of alcohol related products. There would appear to be much justification in the titular 'anti-alcohol crusade'. The results of the Sejm's work was the passing of the Act of $23^{\text {rd }}$ April 1920, which introduced significant limits on the sale of alcoholic drinks. Furthermore, the terms of the Act gave adherents of prohibition some hope of its gradual implementation across the country. During the phase of limiting production, sale and consumption there developed a highly visible conflict between activists fighting with alcoholism and the Government, especially the Treasury Minister. The clash centred around the conflict between ideals and the interests of the national 
budget. This conflict was won decisively by the supporters of limiting the sale of alcohol, although this victory brought nothing tangible as a result, and the Act of $23^{\text {rd }}$ April 1920 was never fully implemented. The final confirmation of this failure was the passing of an Act of $21^{\text {st }}$ March 1931 which limited the sale, serving and consumption of alcoholic drinks (anti-alcohol), which officially marked the return to pragmatism in this area of public life.

Key words: Second Polish Republic, social politics, the fight with alcoholism, the Legislative Sejm, Prohibition 